\title{
Do Hydatellaceae belong to the monocotyledons or basal angiosperms? Evidence from seedling morphology
}

\begin{abstract}
Tillich, H.-J., Tuckett, R. \& Facher, E.: Do Hydatellaceae belong to the monocotyledons or basal angiosperms? Evidence from seedling morphology. - Willdenowia 37: 399-406. - ISSN 05119618 ; (C) 2007 BGBM Berlin-Dahlem.

doi:10.3372/wi.37201 (available via http://dx.doi.org/)

Seedlings of Hydatellaceae are described for the first time. The seedlings of three species from SW Australia, Hydatella dioica, Trithuria submersa and T. bibracteata were investigated. All proved monocotylar, the cotyledon structure as well as the overall seedling morphology being typical for the monocotyledons. The results are discussed in the light of recent molecular analyses. Seedling morphology does not support the assignment of the family to the Nymphaeales and basal angiosperms, respectively.
\end{abstract}

Key words: systematics, Hydatella, Trithuria, cotyledon structure.

\section{Introduction}

The (semi-)aquatic family Hydatellaceae includes two genera: Hydatella Diels, with five species in southern Australia and New Zealand, and Trithuria Hook. f., with three species in Australia and one species in India (Cooke 1987, Yadav \& Janarthanam 1994, 1995, Hamann 1998). The very small, moss-like plants often co-occur with members of Centrolepidaceae. Due to the superficial similarity between Hydatella, Trithuria and Centrolepis, these genera formerly had been placed in the family Centrolepidaceae (Hieronymus 1888, Diels 1936, Hamann 1962, Hutchinson 1973), until Hamann (1976) segregated the Hydatellaceae. This family is characterised by an unusual set of characters that makes recognition of the closest relatives difficult. Traditionally, it was placed in the order Poales (APG 2003, Stevenson \& al. 2000, Linder \& Rudall 2005). Surprisingly, based on a multigenic molecular phylogenetic analysis by Saarela $\&$ al. (2007), Hydatellaceae were assigned to the order Nymphaeales in the basal angiosperms. This is one of the most spectacular new placements of an angiosperm family resulting from a molecular analysis. Unfortunately, the minute plants, having linear leaves and much reduced flowers, provide no obvious morphological characters to assign them to or to exclude them from the monocots. This recently prompted Rudall \& al. (2007) to carry out an extensive anatomical, mor- 
phological and developmental analysis of vegetative and floral characters of the family. Their results underline the isolated position of the family, and neither monocots, Nymphaeales, other basal angiosperms nor fossils proved as close relatives. However, the seedling structure of Hydatellaceae remained very incompletely known, as there exists only a superficial description of a Trithuria seedling (Cooke 1983). The number of cotyledons in the Hydatellaceae and the presence or absence of the basic morphological seedling characters distinguishing monocots from all other angiosperms are still unknown. This stimulated the following analysis of $\mathrm{Hyda}$ tellaceae seedlings.

\section{Material and methods}

We analysed seedlings of three species occurring in SW Australia:

- Trithuria submersa Hook. f.: Mersea Road Swamp, at Palgarup, 34²8'07"S; 116 $12^{\circ} 12^{\prime \prime E}$, in a claypan vernal pool, wet but not inundated, 27.10.2006, R. Tuckett RTUC 016.

- Trithuria bibracteata D. A. Cooke: Mersea Road Swamp, at Palgarup, 34²8'07"S, 116 $12^{\prime} 12^{\prime \prime E}$, in a claypan vernal pool, wet but not inundated, 27.10.2006, R. Tuckett RTUC 017.

- Hydatella dioica D. A. Cooke: Tolkenup Swamp, 34¹9'19"S, 116²9.9'43"E, 26.10.2006, $R$. Tuckett RTUC 015.

Voucher specimens are deposited at PERTH. Seeds and seedlings are stored in the monocots seedling collection at the Institute of Systematic Botany, Ludwig-Maximilian-University $\mathrm{Mu}-$ nich (MSB).

A first set of seeds was sown at the Botanic Gardens \& Parks Perth, AU. Temperatures of 10$15{ }^{\circ} \mathrm{C}$ and provision of daylight proved as best germination conditions. A second set was grown at the Institute of Systematic Botany, LMU Munich, Germany, under similar conditions. Seedlings were fixed in FAA, transferred to $50 \%$ acetone, dissected, dehydrated through absolute acetone, critical point dried, mounted on specimen stubs using double-sided tape, coated with gold using a sputter coater SCD 050 (BAL-TEC AG, Liechtenstein) and viewed and photographed in a scanning electron microscope (SEM) LEO $438 \mathrm{VP}$.

\section{Results}

Fruits and seeds. - The fruits of both Trithuria species are thin-walled, triquetrous, 1-seeded capsules with three prominent, equally spaced ribs following the veins (Fig. 1A). Dehiscence commences with longitudinal slits opening along the ribs (Fig. 1A). In the final stage, three valves and three ribs are separated, but remain connected in the distal region. The ribs then are twisted, obviously due to hygroscopic movement (Fig. 1B). This confirms the observations of Hamann \& al. (1979) and Rudall \& al. (2007). The surface of the outer fruit epidermis is densely studded with irregularly shaped and partly confluent wax deposits (Fig. 1D). The single seed usually remains attached to the open fruit at the distal pole, even during germination (Fig. 2A). In Hydatella, in contrast, the capsule is ovoid and lacks prominent ribs. The fruit wall is firmly fixed to the seed coat, and the seed remains inside the fruit (Fig. 1E). The seeds of T. bibracteata are blackish brown and ovoid, those of T. submersa are beige and more diverse in shape, ranging from ovoid to narrowly drop-shaped. At the micropylar pole the seeds of both species bear a conical, small-celled protuberance (Fig. 1C, F).

Seedlings. - The seedlings of Trithuria submersa and T. bibracteata are nearly identical in structure, therefore only those of T. submersa are described here in detail. The terminology follows the definitions in Tillich (2007). Under natural conditions, the germination commences while the seed is still attached to the opened fruit. Even remnants of stylar hairs can be still found at this stage (Fig. 2A). To study the seedling in detail, the seed must be detached from the fruit wall. During germination, the conical seed protuberance is pushed away. It obviously represents an operculum, formed from the testa layer. Very unusual are the tegmen cells facing the embryo. These cells expand considerably, following the growth of the seedling. The base of fully devel- 

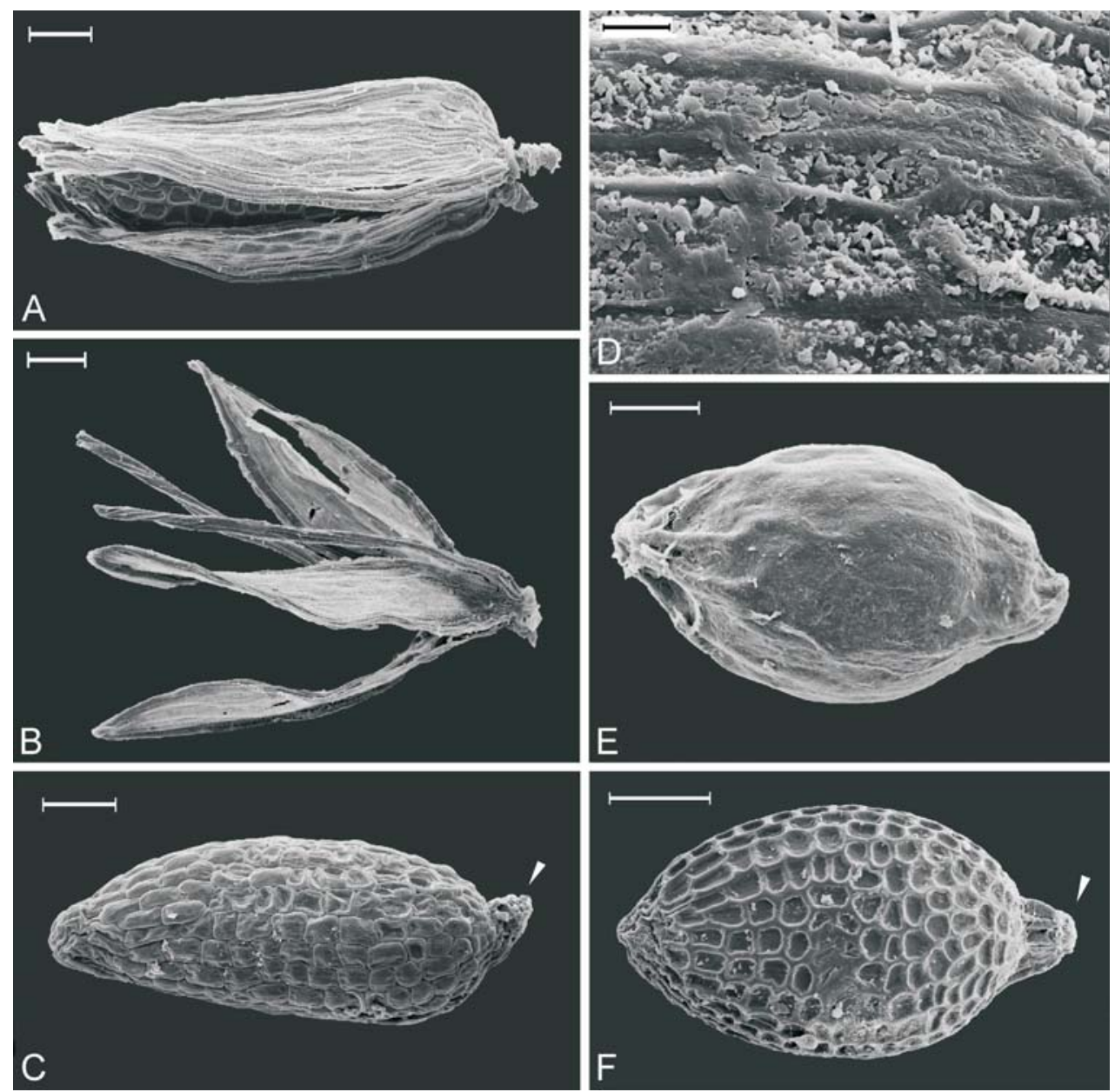

Fig. 1. Fruits and seeds of Hydatellaceae - A-D: Trithuria submersa; A: start of fruit dehiscence with a slit along a rib, note the seed inside; B: fully opened fruit, valves and ribs (one rib lost during preparation) are separated but remain fused at the distal pole; C: seed; D: epicuticular wax deposits on the outer fruit epidermis; E: fruit of Hydatella dioica; F: seed of Trithuria bibracteata. - The arrow heads in $\mathrm{C}$ and $\mathrm{F}$ point to the micropylar pole; scale bars: A-C, E-F $=100 \mu \mathrm{m}, \mathrm{D}=10 \mu \mathrm{m}$.

oped seedlings is embraced by this one-layered tegmen tissue (Fig. 2E). The tegmen cells are very flat but much expanded in area. Their surface shows radial ridges and furrows (Fig. 2F). Among more than 50 seedlings studied, we found only one in which the tegmen cover was disrupted (Fig. 2D). The operculum is usually shed, but in a few seedlings we found it still attached to the tegmen layer (Fig. 2B, C).

The seedlings are unambiguously monocotylar. The cotyledonary haustorium - a globose, unifacial structure corresponding to the hyperphyll (Oberblatt) of the cotyledon - is hidden in the seed, being in contact with the nutritive tissues. When the seedling is carefully detached from the seed, the unifacial haustorium becomes visible (Fig. 2E, F). The cotyledonary sheath bears two conspicuous sheath lobes (Fig. 2A, B, D, E). The first plumular leaf is a cylindrical, green eophyll (Fig. 2B). A hypocotyl is clearly recognizable (Fig. 2B-F). At the base of the hypocotyl there is a collar consisting of 2(-3) epidermal cell rows, each of these cells bearing a rhizoid (Fig. 2C, F). 

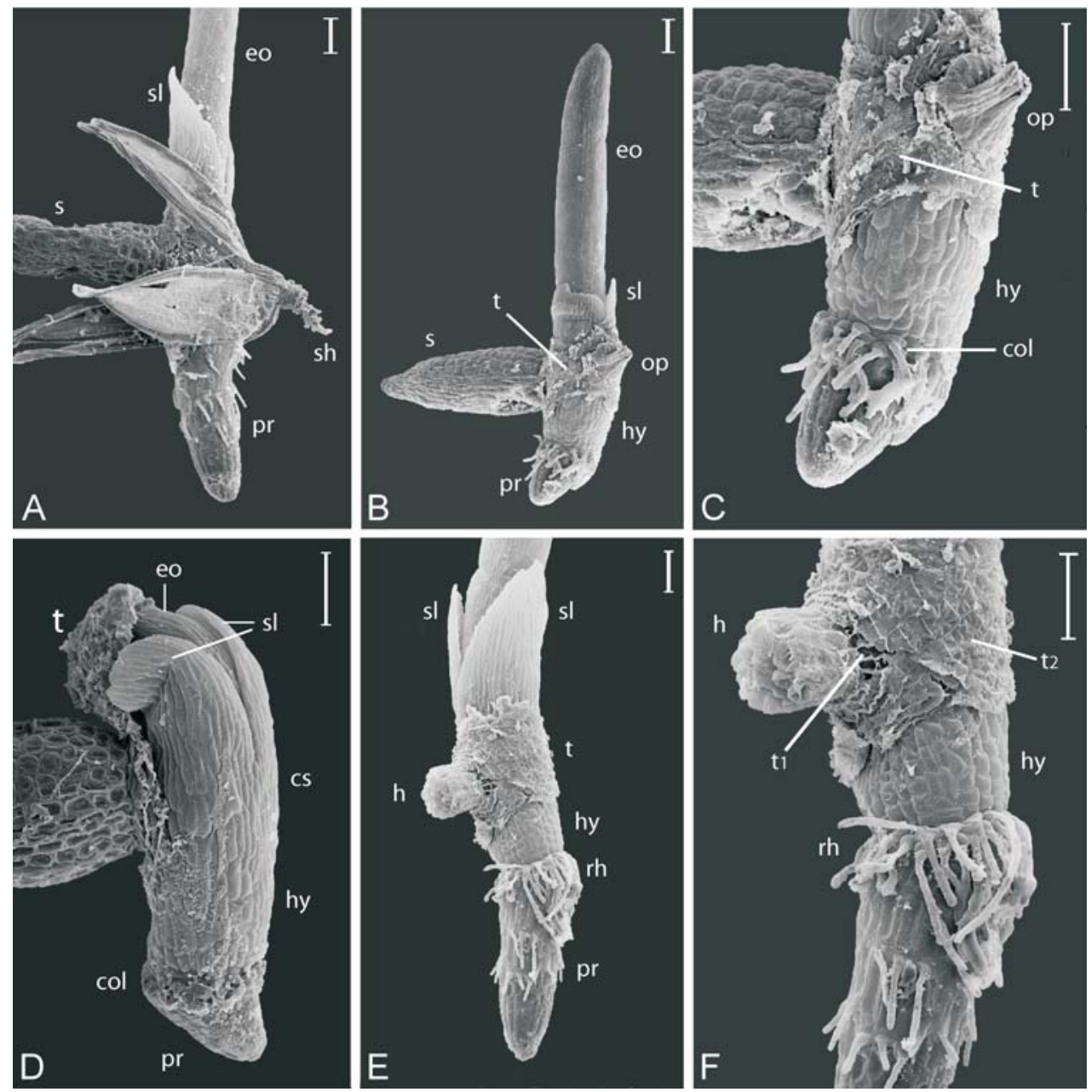

Fig. 2. Seedlings of Trithuria submersa - A: seedling still attached to the opened fruit; B: seedling with the operculum attached to the tegmen; C: close-up of B; D: young seedling with the tegmen disrupted and turned up; E: seedling detached from the seed to show the haustorium; F: close-up of E. - Further explanation in the text. $-\mathrm{col}=$ collar, $\mathrm{cs}=$ cotyledonary sheath, $\mathrm{eo}=$ eophyll, $\mathrm{h}=$ haustorium, hy $=$ hypocotyl, op $=$ operculum, $\mathrm{pr}=$ primary root, $\mathrm{rh}=$ collar rhizoids, $\mathrm{s}=$ seed, $\mathrm{sh}=$ remnants of stylar hairs, $\mathrm{sl}=$ sheath lobes, $\mathrm{t}=$ tegmen, $\mathrm{t} 1=$ stiff tegmen cells, $\mathrm{t} 2=$ distended tegmen area, originally facing the embryo inside the seed, the cell surface with radial ridges and furrows; scale bars $=100 \mu \mathrm{m}$.

The primary root grows moderately in length, root hairs are produced only from short cells of the rhizodermis. Another detail can be observed in detached seedlings (Fig. 2F): there is a sharp delimitation between the "normal" tegmen cells and those expanding during germination. The tegmen cells accompanying the inner testa surface are stiff and unable to expand (t1 in Fig. 2F).

The seedling structure in Hydatella dioica differs in some details from Trithuria. Here again, the germinating seedling pushes the operculum away (Fig. 3C). But, in contrast to Trithuria, the tegmen has only limited capacity to dilate and is soon disrupted, thus never embracing the seedling base (Fig. 3B). The delimitation between the cotyledonary sheath and the hypocotyl is clearly marked by the different epidermis pattern (Fig. 3A-C, E, F). The cotyledonary sheath also bears two sheath lobes, but the basally closed sheath part is somewhat elongated, thus repre- 

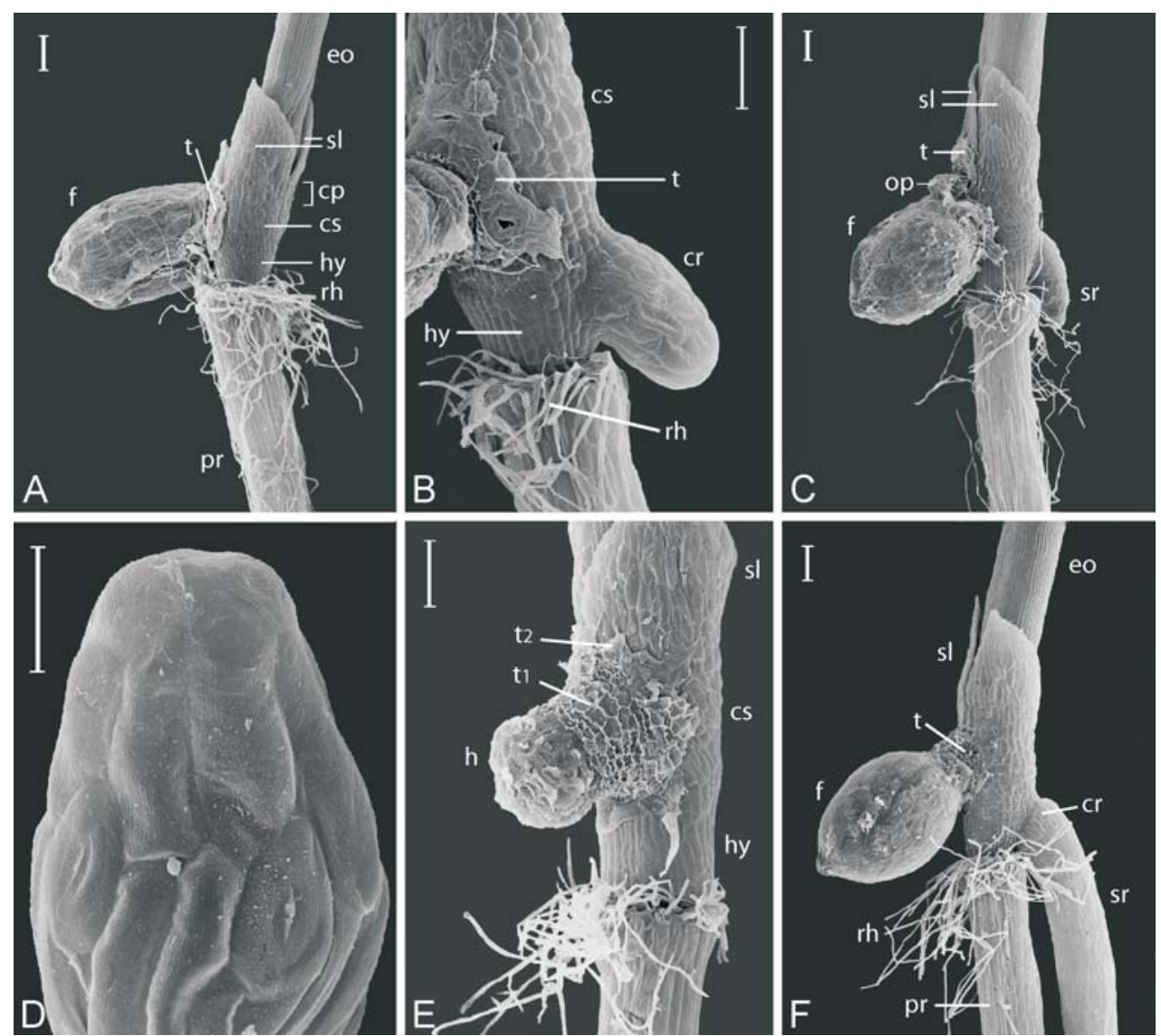

Fig. 3. Hydatella dioica - A: seedling, the cotyledonary sheath with a low coleoptile; B: seedling base, a shoot-born root is still covered by a coleorhiza; note the distended but disrupted tegmen; C: seedling with the operculum attached; D: eophyll tip, showing stomata; E: seedling detached from the seed, the unifacial haustorium and cotyledonary sheath partly covered by tegmen material; F: an older seedling with developed shoot-born root. - Further explanation in the text; $\mathrm{cp}=$ coleoptile, $\mathrm{cr}=$ coleorhiza, $\mathrm{cs}=$ cotyledonary sheath, eo $=$ eophyll, $\mathrm{f}=$ fruit, $\mathrm{h}=$ haustorium, hy $=$ hypocotyl, $\mathrm{op}=$ operculum, $\mathrm{pr}=$ primary root, $\mathrm{rh}=$ collar rhizoids, $\mathrm{sl}=$ sheath lobes, $\mathrm{sr}=$ shoot-born root, $\mathrm{t}=$ tegmen, $\mathrm{t} 1=$ stiff tegmen cells, $\mathrm{t} 2=$ distending tegmen cells; scale bars $=\mathrm{A}-\mathrm{C}, \mathrm{E}-\mathrm{F}=100 \mu \mathrm{m}, \mathrm{D}=20 \mu \mathrm{m}$.

senting a low coleoptile (Fig. 3A) (see discussion below). The first eophyll is green and cylindrical. Stomata are rare along this leaf but more densely present at the leaf tip (Fig. 3D). At the base of the hypocotyl, there is a collar with two rows of epidermal cells producing long rhizoids. However, this region is somewhat hidden due to a swelling of the primary root base (Fig. 3B, E, F). A first shoot-born root develops inside the hypocotyl, at first covered by a well-developed coleorhiza (Fig. 3B). After breaking through, the coleorhiza remains as a cuff around the root base. The endogenous root grows rapidly and soon equals the primary root (Fig. 3F).

\section{Discussion}

Seedling morphology. - A unique character is the tegmen layer covering the seedling base in Trithuria (Fig. 2B, C, E, F). Hamann (1975) and Hamann \& al. (1979) have demonstrated the presence of a modified tegmen area facing the embryo in the ripe seed and interpreted it as an 
operculum. Similarly, Cooke (1983), in his sketch of a Trithuria seedling, refers to the expanding cover as a "distended operculum". The present study of the germination process revealed that an operculum, i.e. a rigid germination lid, is formed by the conical structure at the micropylar seed pole (Fig. 2B, C). It originates from the outer seed coat (testa) and is split off at the earliest germination stage. The role of the conspicuous tegmen cells facing the undifferentiated embryo during germination is not comparable to that of true operculum. A distended tegmen enveloping the youngest seedling stage and later surrounding the seedling base is unknown among other angiosperms.

Of special interest are the two prominent cotyledonary sheath lobes. They embrace and protect the young first eophyll, functionally representing a coleoptile. In a number of Hydatella seedlings the cotyledonary sheath was found to be elongated to some degree and to form a short tube, thus indeed representing a short coleoptile, expanded with two lateral lobes (Fig. 3A). Functionally, the paired structure elongating the cotyledonary hypophyll is a coleoptile more or less divided into two halves.

The germination of Centrolepis is epigeal (Hieronymus 1873, Tillich 1995, 2007), the seedlings have no similarity to those of Hydatellaceae.

Systematic position of Hydatellaceae. - The transfer of the poorly known Hydatellaceae from highly advanced Poales to the Nymphaeales in the basal angiosperms has brought this family into the focus of modern systematic research. Rudall \& al. (2007) have increased our knowledge by presenting a great wealth of new details. All non-molecular characters hitherto known point to a much isolated position of the family, but give no indication of any close relatives. According to the present study, the seedlings of Hydatellaceae are unambiguously monocotylar. Outsides monocots, monocotylar seedlings are known only in a few eudicots, summarised by Haccius (1953) and Hamann (1977). However, the difference between seedlings of the monocots and other angiosperms is not only defined by the number of cotyledons, but also by their structure (Tillich 2007). Cotyledons of basal angiosperms as well as eudicots always possess a distinct (though sometimes very short) petiole and a bifacial lamina, independent of whether the cotyledons are haustorial, storing, or photosynthetic. In monocotylar seedlings of eudicots the lamina of the single cotyledon is not distinct from those of closely related dicotylar taxa (Winkler 1931, Haccius 1952, 1954, Haccius \& Hartl-Baude 1956, Haccius \& Fischer 1959, Förster 1997). The cotyledon in Hydatella and Trithuria is, however, unambiguously of the type restricted to the monocotyledons. This is in conflict with the molecular results of Saarela \& al. (2007), who identified Hydatellaceae as sister to Nymphaeales. Seedlings of Nyphaeaceae and Cabombaceae are dicotylar (Goebel 1891, Tillich 1990). The aquatic habitat is not correlated in any way with the seedling structure. Even the highly derived aquatic Podostemaceae have retained dicotylar seedlings (Cook \& Rutishauser 2007). All monocotylar eudicots so far known are land plants.

The structural difference between the cotyledon of monocotyledons and all the other seed plants is a principal characteristic. The evolution of the monocotyledonous embryo/seedling required a profound reorganisation of the plant body. No reversal is known. Therefore, it is not very likely that such a profound reorganisation has evolved twice in the same way. If Hydatellaceae is indeed correctly placed along with Nymphaeales, the evolution of the single cotyledon along this branch would be enigmatic.

A second character of the family that is typical of monocots are the sieve tube plastids of the P2c subtype (Behnke 2000). This plastid type with triangular crystalloid protein bodies is found throughout the monocotyledons with the only exception of Pistia (S-type plastids, Behnke 1995). Outsides the monocots, P2c plastids are known only in Asarum and Saruma (Aristolochiaceae), but their seedlings are dicotylar (Tillich, unpubl.). Hitherto, the combined occurrence of a single cotyledon with typical monocotyledonous structure and P2c plastids is known only in monocotyledons. It would be difficult to understand that the combination of two highly derived characters should have evolved independently in the monocotyledons and a family sister to Nymphaeales close to the angiosperm stem group. A critical reconsideration of the results of Saarela \& al. (2007) seems appropriate, the more as the results of Stevenson \& al. (2000), APG 
(2003) and Michelangeli \& al. (2003) are in line with the traditional position of the family in the Poales and monocotyledons.

\section{Acknowledgements}

We are grateful to Barbara Briggs (Sydney) and Anton Weber (Vienna) for helpful comments, and we thank Emilia Vosyka for careful technical assistance.

\section{References}

Angiosperm Phylogeny Group (APG) 2003: An update of the Angiosperm Phylogeny Group classification for the orders and families of flowering plants: APG II. - Bot. J. Linn. Soc. 141: 399-436. [CrossRef]

Behnke, H.-D. 1995: P-type plastids and the systematics of the Arales (sensu Cronquist 1988) with S-type plastids in Pistia. - Pl. Syst. Evol. 195: 87-119.

- 2000: Forms and sizes of sieve-element plastids and evolution of the monocotyledons. - Pp. 163-188 in: Wilson, K. L. \& Morrison, D. A. (ed.), Monocots. Systematics and evolution. Melbourne.

Cook, C. D. K. \& Rutishauser, R. 2007: Podostemaceae. - Pp. 304-344 in: Kubitzki, K. (ed.), The families and genera of vascular plants 9. Flowering plants. Eudicots. Berberidopsidales through Sabiaceae. - Berlin, etc.

Cooke, D. A. 1983: The seedling of Trithuria (Hydatellaceae). - Victorian Naturalist 100(2): 68-69.

- 1987: Hydatellaceae. - Pp. 1-5 in: George, A. S. (ed.), Flora of Australia 45. - Canberra.

Diels, L. 1936: Engler's Syllabus der Pflanzenfamilien, ed. 11. - Berlin.

Förster, P. 1997: Die Keimpflanzen der Tribus Ranunculeae DC. und der Tribus Adonideae Kunth (Ranunculaceae). - Flora 192: 133-142.

Goebel, K. 1891: Pflanzenbiologische Schilderungen. 2. Teil. - Marburg.

Haccius, B. 1952: Verbreitung und Ausbildung der Einkeimblättrigkeit bei den Umbelliferen. Österr. Bot. Z. 99: 483-505. [CrossRef]

- 1953: Embryologische und histogenetische Untersuchungen an "monokotylen Dikotylen". Bau und Funktion des Keimblattstiels. - Ber. Deutsch. Bot. Ges. 66: 17-19.

- 1954: Embryologische und histogenetische Studien an "monokotylen Dikotylen" 1. Claytonia virginica L. - Österr. Bot. Z. 101: 285-303. [CrossRef]

— \& Fischer, E. 1959: Embryologische und histogenetische Studien an "monokotylen Dikotylen" III. Anemone appenina L. - Österr. Bot. Z. 106: 373-389. [CrossRef]

— \& Hartl-Baude, E. 1956: Embryologische und histogenetische Studien an "monokotylen Dikotylen” II. Pinguicula vulgaris L. und Pinguicula alpina L. - Österr. Bot. Z. 103: 567-587. [CrossRef]

Hamann, U. 1962: Beitrag zur Embryologie der Centrolepidaceae mit Bemerkungen über den Bau der Blüten und Blütenstände und die systematische Stellung der Familie. - Ber. Deutsch. Bot. Ges. 75: 153-171.

- 1975: Neue Untersuchungen zur Embryologie und Systematik der Centrolepidaceae. - Bot. Jahrb. Syst. 96: 154-191.

- 1976: Hydatellaceae - a new family of Monocotyledoneae. - New Zealand J. Bot. 14: 193-196.

- 1977: Über Konvergenzen bei embryologischen Merkmalen der Angiospermen. - Ber. Deutsch. Bot. Ges. 90: 369-384.

- 1998: Hydatellaceae. - Pp. 231-234 in: Kubitzki, K. (ed.), The families and genera of vascular plants 4. Flowering plants. Monocotyledons. Alismatanae and Commelinanae. - Berlin, etc.

— , Kaplan, K. \& Rübsamen, T. 1979: Über die Samenschalenstruktur der Hydatellaceae (Monocotyledoneae) und die systematische Stellung von Hydatella filamentosa. - Bot. Jahrb. Syst. 100: 555-563. 
Hieronymus, G. 1873: Beiträge zur Kenntnis der Centrolepidaceen. - Abh. Naturf. Ges. Halle 12: $115-222$.

- 1888: Centrolepidaceae. - Pp. 11-16 in: Engler, A. \& Prantl, K. (ed.), Die natürlichen Pflanzenfamilien II(4). - Leipzig.

Hutchinson, J. 1973: The families of flowering plants, ed. 3. - Oxford.

Linder, H. P. \& Rudall, P. J. 2005: Evolutionary history of Poales. - Annual Rev. Ecol. Syst. 35: 107-124.

Michelangeli, F. A., Davis, J. I. \& Stevenson, D. W. 2003: Phylogenetic relationships among Poaceae and related families as inferred from morphology, inversions in the plastid genome, and sequence data from the mitochondrial and plastid genoms. - Amer. J. Bot. 90: 93-106.

Rudall, P. J., Sokoloff, D. D., Remizova, M. V., Conran, J. G., Davis, J. I., Macfarlaine, T. M. \& Stevenson, D. W. 2007: Morphology of Hydatellaceae, an anomalous aquatic family recently recognized as an early divergent angiosperm lineage. - Amer. J. Bot. 94: 1033-1092.

Saarela, J. M., Rai, H. S., Doyle, J. A., Endress, P. K., Matthews, S., Marchant, A. D., Briggs, B. G. \& Graham, S. W. 2007: Hydatellaceae identified as a new branch near the base of the angiosperm phylogenetic tree. - Nature 446: 312-315. [CrossRef]

Stevenson, D. W., Davis, J. I., Freudenstein, J. V., Hardy, C. R., Simmons, M. P. \& Specht, C. D. 2000: A phylogenetic analysis of the monocotyledons based on morphological and molecular character sets, with comments on the placement of Acorus and Hydatellaceae. - Pp. 17-24 in: Wilson, K. L. \& Morrison, D. A. (ed.), Monocots. Systematics and evolution. Collingwood.

Tillich, H.-J. 1990: Die Keimpflanzen der Nymphaeaceae - monocotyl oder dicotyl? - Flora 184: $169-176$.

- 1995: Seedlings and systematics in monocotyledons. - Pp. 303-352 in: Rudall, P. J., Cribb, P. J., Cutler, D. F. \& Humphries, C. J. (ed.), Monocotyledons: systematics and evolution. Kew.

- 2007: Seedling diversity and the homologies of seedling organs in the order Poales (Monocotyledons). - Ann. Bot. (Oxford) 100 (in press).

Winkler, H. 1931: Die Monokotylen sind monokotyl. - Beitr. Biol. Pfl. 19: 29-34.

Yadav, S. R. \& Janarthanam, M. K. 1994: Hydatellaceae: a new family to Indian flora with a new species. - Rheedea 4: 17-20.

— \& - 1995: Trithuria konkanensis (Hydatellaceae), eine neue Art aus Indien. - Aqua Pl. 20: 91-97.

Addresses of the authors:

Hans-Jürgen Tillich and Eva Facher, Ludwig-Maximilians-Universität München, Fakultät für Biologie, Systematische Botanik, Menzingerstr. 67, D-80638 München, Germany; e-mail: hjtillich@1rz.uni-muenchen.de

Renee Tuckett, Botanic Gardens \& Park Authority, Fraser Avenue, West Perth WA 6005, Australia; e-mail: Renee.Tuckett@bgpa.wa.gov.au 